\title{
Skyndilegur brjóstverkur og raddbreyting eftir notkun rafsígarettu
}

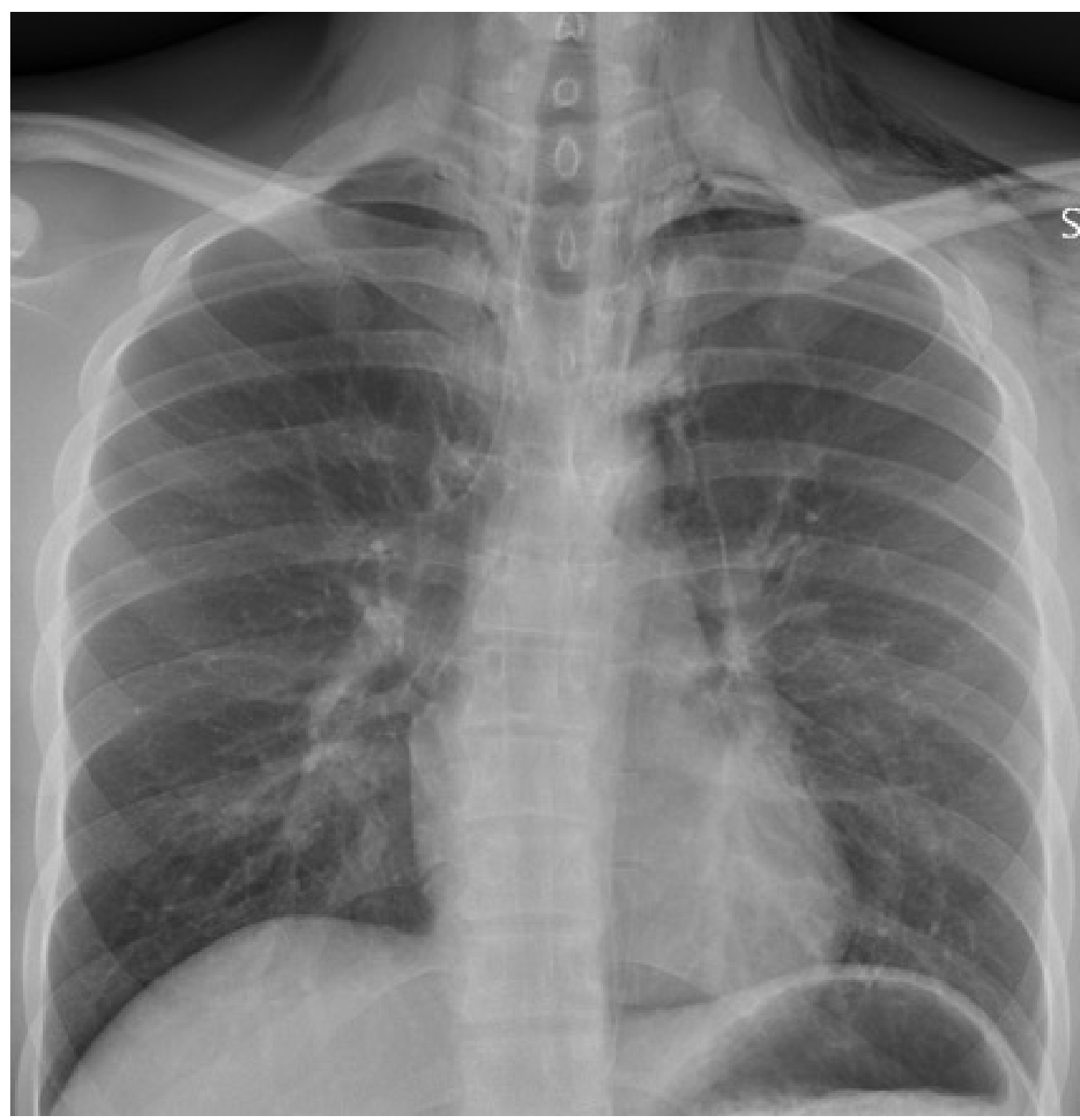

Mynd 1. Röntgenmynd af lungum tekin við komu.

\section{Úlfur Thoroddsen ${ }^{1}$ læknir}

\section{Tómas Guðbjartsson ${ }^{1,2}$ |æknir}

${ }^{1}$ Hjarta- og lungnaskurðdeild Landspítala ¿Læknadeild Háskóla Íslands

Fyrirspurnum svarar Úlfur Thoroddsen, ulfurtho@landspitali.is

https://doi.org/10.17992/lbl.2019.06.237
Tæplega tvítugur, áður hraustur, fyrrverandi reykingamaður leitaði á bráðamóttöku Landspítala vegna skyndilegra brjóstverkja. Tveimur klukkustundum áður hafði hann notað rafsígarettu sem olli kröftugu hóstakasti. Verkurinn versnaði við djúpa innöndun en hann fann einnig fyrir verkjum við hreyfingu og kyngingu, auk pess sem rödd varð rámari. Við skoðun var hann ekki bráðveikur né meðtekinn af verkjum að sjá og með eðlileg lífsmörk. Brak fannst við preifingu efst á bringu og við háls. Lungna- og hjartahlustun var eðlileg. Tekin var röntgenmynd af lungum sem sýnd er á mynd 1.

Hver er greiningin? Parf frekari rannsóknir og í hverju er meðferð fólgin? 
Svar: Sjálfsprottið loftmiòmæti (spontaneous pneumomediastinum)

Sjúklingurinn er með dæmigerð einkenni og teikn loftmiðmætis en á mynd 1 sést greinileg loftrönd í kringum hjartað. Loftið teygir sig upp í miðmæti og háls par sem loft undir húð er áberandi, og kallast húðnetjupemba (subcutaneous emphysema).

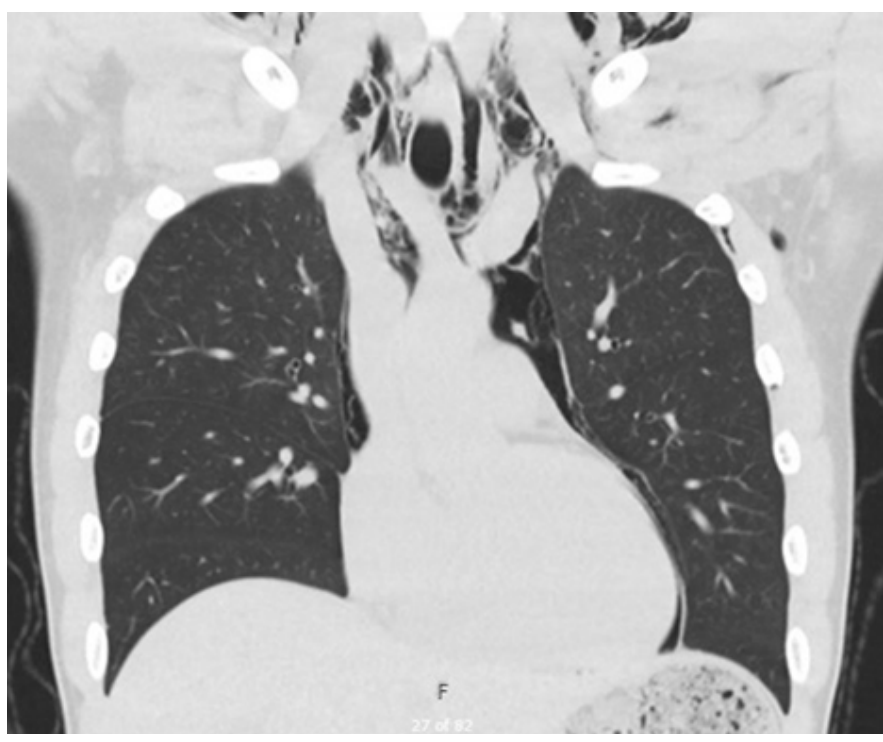

Mynd 2. Tölvusneiðmynd af brjóstkassa tekin nokkrum klukkustundum frá komu.

Greiningin var staðfest með tölvusneiðmynd sem sýnd er á mynd 2, en par sést loftið í miðmæti og undir húð enn betur en á hefðbundinni lungnamynd. Jafnframt sýna tölvusneiðmyndirnar hvorki loftbrjóst, sem er helsta mismunagreiningin, né blöðrur (blebs) í lungum.

Loftmiðmæti er oftast af ópekktum orsökum og er pá kallað sjálfsprottið (spontaneous). Aðrar ástæður geta verið af læknisvöldum (vélindaspeglun, berkjuspeglun, sýnatökur á lungum, yfirprýstingur í öndunarvél), eftir háorkuáverka eða sem afleiðingar sjúkdóma eins og langvinnrar lungnateppu, lungnatrefjunar (interstitial lung disease) eða krabbameins í lungum. ${ }^{1}$ Loftmiðmæti vegna rofs á vélinda getur fylgt miðmætisbólga (mediastinitis) sem er lífshættuleg sýking sem mikilvægt er að útiloka.

Sjúklingurinn í pessu tilfelli hafði hvorki hita né hækkun á C-reactive próteini (CRP) eða hvítum blóðkornum sem fylgir miðmætisbólgu og pví ekki talin ástæða til frekari myndrannsókna eins og skuggaefnisrannsóknar á vélinda eða tölvusneiðmynda-

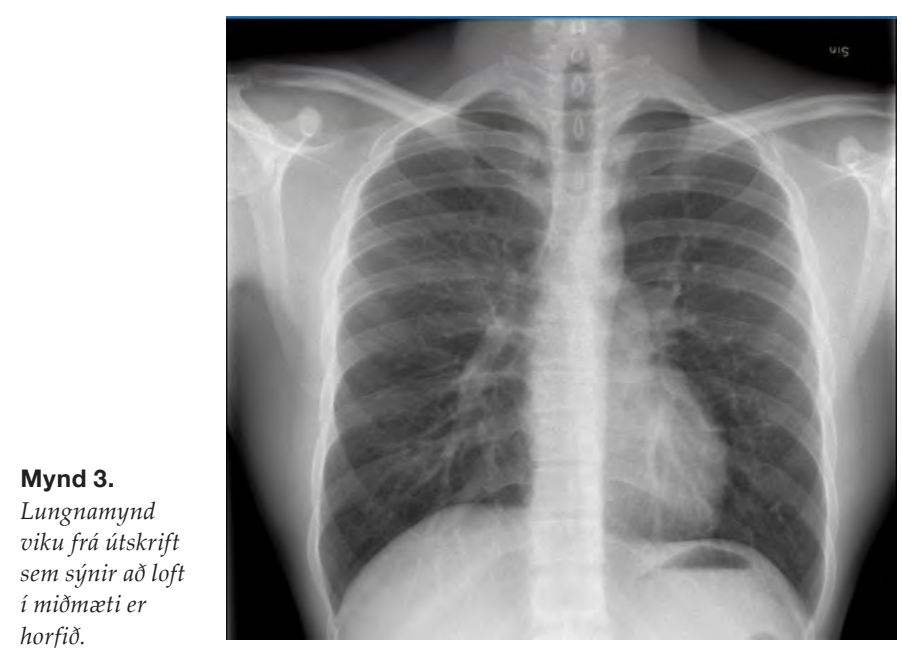

rannsóknar á vélinda og miðmæti. Hann var lagður inn og fékk verkjalyf. Endurteknar mælingar á CRP og hvítum blóðkornum sýndu eðlileg gildi og röntgenmyndir af lungum sem teknar voru næstu tvo daga sýndu minnkandi loftmiðmæti. Sjúklingurinn var útskrifaður heim við góða líðan tveimur sólarhringum frá upphafi einkenna. Við eftirfylgd rúmri viku síðar sýndi röntgenmynd af lungum (mynd 3) að loft sást ekki lengur í miðmæti.

Líkleg orsök fyrir loftmiðmæti í pessu tilfelli er yfirprýstingur (barotrauma) sem myndaðist í lungum og berkjum. Pað má rekja til hóstakasta eftir innöndun á ertandi gufum úr rafsígarettu en pessum gufum er oft andað djúpt inn í lungu og haldið niðri til að fá sem mest nikótín inn í blóðrásina.

Loftið hefur rifið gat á lungað og brýtur sér síðan leið inn í miðmæti, í stað pess að fara út í gegnum fleiðru lungans (parietal pleura) og valda loftbrjósti.

Til eru mörg sjúkratifelli af loftmiðmæti eftir kannabisreykingar $^{2}$ og neyslu krakks/kókaíns (crack cocaine) ${ }^{3}$ en einungis einu tilfelli hefur áður verið lýst eftir notkun rafsígarettu. ${ }^{4}$ I öllum tilvikum er reynt að halda vímuefninu sem lengst í lunganu, sem veldur hóstakasti, jafnvel á lokaðan öndunarveg.

Sjálfsprottið loftmiðmæti er ekki algengur sjúkdómur hjá fullorðnum en greinist helst hjá ungum karlmönnum ${ }^{5-6}$. Algengasta einkennið, eins og í pessu tilfelli, er skyndilegur brjóstverkur, yfirleitt undir bringubeini, sem leiðir upp í háls og/eða aftur í bak. Einnig eru andnauð, hósti, verkur í hálsi, ógleði og/eða uppköst algengar kvartanir auk ópæginda við kyngingu og raddbreytingu sem skýrist af loftsöfnun við raddbönd. ${ }^{5,6}$

Pótt rafsígarettur geti hjálpað fólki að hætta reykingum ${ }^{7}$ getur peim fylgt erting í öndunarvegum sem jafnvel getur valdið alvarlegum fylgikvillum eins og loftmiðmæti.

\section{Heimildir}

1. Vasileios K. Kouritas, Konstantinos Papagiannopoulos, George Lazaridis, Sofia Baka, Ioannis Mpoukovinas, Vasilis Karavasilis, et al. Pneumomediastinum. J Thorac Dis. 2015;7:S44-9.

2. Hazouard E, Koninck JC, Attucci S, Fauchier-Rolland F, Brunereau L, Diot P. Pneumorachis and pneumomediastinum caused by repeated Müller's maneuvers: complications of marijuana smoking. Ann Emerg Med. 2001;38:694-7.

3. Janes S.M., Ind P.W., Jackson J. Images in thorax. Crack inhalation induced pneumomediastinum. Thorax. 2004;59:360.

4. Rita D. Marasco, Domenico Loizzi, Nicoletta P. Ardò, Fabio N. Fatone, Francesco Sollitto. Spontaneous Pneumomediastinum After Electronic Cigarette Use. The Annals of Thoracic Surgery. June 2018;6:e269-71.

5. Macia I, Moya J, Ramos R, et al. Spontaneous pneumomediastinum: 41 cases. Eur J Cardiothorac Surg. 2007;31:1110-4.

6. Manuel Caceres, Syed Z.Ali, Rebecca Braud, Darryl Weiman, H. Edward Garrett Jr. Spontaneous Pneumomediastinum: A Comparative Study and Review of the Literature. The Annals of Thoracic Surgery, 2008;3:962-6.

7. Peter Hajek, Anna Phillips-Waller, Dunja Przulj, Francesca Pesola,, Katie Myers Smith, Natalie Bisal, et al. A Randomized Trial of E-Cigarettes versus Nicotine-Replacement Therapy. N Engl J Med 2019; 380:629-37.

\section{Case of the month: Sudden chest pain and changed voice after the use of an electronic cigarette}

\section{Úlfar Thoroddsen ${ }^{1}$}

Tómas Guðbjartsson ${ }^{1,2}$

${ }^{1}$ Department of Cardiothoracic Surgery, Landspitali University Hospital, ${ }^{2}$ Faculty of Medicine, University of Iceland.

Keywords: Pneumomediastinum, E-cigarette, Electronic cigarette, chest pain, change in voice, vocal change, Spontaneous pneumomediastinum.

Correspondence: Úlfur Thoroddsen, ulfurtho@landspitali.is 